\title{
Removal of iron and manganese from groundwater: a study of using potassium permanganate and sedimentation
}

\author{
Mohamed Elsheikh ${ }^{1, *}, H$. Guirguis ${ }^{1}, A$. Fathy ${ }^{1}$ \\ ${ }^{1}$ Civil Engineering Department, Faculty of Engineering, Menoufia University, Egypt
}

\begin{abstract}
Experiments are done for different combinations of $\mathrm{Fe}+2$ and $\mathrm{Mn}+2$ concentrations. The obtained results show that Potassium Permanganate (PP) gives good results in iron and manganese removal. By using PP dose near to half of the theoretically required one, it can remove up to $100 \%$ and $90 \%$ of iron and manganese, respectively over different tested concentrations at $\mathrm{pH}=7.0$. Increasing rate of filtration influences the $\mathrm{Mn}+2$ removal process obviously. Sedimentation is required when combined concentrations of iron and manganese are greater than $5.0 \mathrm{ppm}$ to reduce filter rapid clogging. Using conventional treatment with adding alum, flocculation, sedimentation and filtration can remove up to $97 \%$ and $18 \%$ of iron and manganese, respectively. Using PP in addition to alum enhances manganese removal but decreases iron removal. However, using alum with increasing $\mathrm{pH}$ to 10 leads to $100 \%$ and $95 \%$ of $\mathrm{Fe}^{+2}$ and $\mathrm{Mn}^{+2}$ removal and increases filter working period.
\end{abstract}

\section{INTRODUCTION}

Groundwater sources in Egypt can be divided into renewable aquifers like Nile valley and Delta and non-renewable aquifers like the aquifer of the western desert in the Nubian sandstone [1]. Iron and manganese are usually present in groundwater as dissolved minerals or associated with other components [2]. Existence of iron and manganese in water causes many problems like water coloring and taste, clothes staining and encouraging bacterial growth in water distribution networks which affect the pipes transfer efficiency [3] but in general they do not cause health problems [4]. The secondary maximum contaminant levels for iron and manganese are $0.3 \mathrm{mg} / 1$ and $0.05 \mathrm{mg} / 1$, respectively [5]. The most common methods used to remove iron and manganese include oxidation by aeration, chlorine, chlorine dioxide, potassium permanganate and/or ozone followed by filtration alone or sedimentation and filtration $[6,7]$. There are other methods that can also be used like using filters with special media like green sand, using ion exchange, biological methods or membrane filtration [8].

Potassium Permanganate (PP) is considered a stronger oxidant and has many advantages over other oxidants. Oxidation chemistry of iron and manganese by PP can be described as follows [9]:

$$
\begin{gathered}
3 \mathrm{Mn}^{+2}+2 \mathrm{KMnO}_{4}+2 \mathrm{H}_{2} \mathrm{O} \longrightarrow \\
5 \mathrm{MnO}_{2}+2 \mathrm{~K}^{+}+4 \mathrm{H}^{+} \ldots \ldots \ldots \ldots \ldots \ldots \\
3 \mathrm{Fe}^{+2}+\mathrm{KMnO}_{4}+7 \mathrm{H}_{2} \mathrm{O} \\
3 \mathrm{Fe}(\mathrm{OH})_{3}+\mathrm{K}^{+}+\mathrm{MnO}_{2}+5 \mathrm{H}^{+} \ldots \ldots \ldots \ldots \ldots \ldots
\end{gathered}
$$

To oxidize one $\mathrm{mg}$ of iron and one $\mathrm{mg}$ of manganese, about $0.94 \mathrm{mg}$ and $1.92 \mathrm{mg}$ of PP are required, respectively [10].

When iron and manganese exist in high concentrations, the filter runs less than 24 hours so a clarification step is needed before filtration to increase the filtration period [11]. So, treatment method would there include flocculation, sedimentation and filtration stages. [12]

This paper studies using PP followed by filtration only or using PP and/or alum (Al) followed by flocculation, sedimentation and 
filtration for $\mathrm{Fe}^{+2}$ and $\mathrm{Mn}^{+2}$ oxidation and removal.

\section{MATERIALS AND METHODS:}

\subsection{Study Method:}

Simulated groundwater was prepared by adding salts of iron and manganese to tap water. The study consists of three groups of experiments: the first one discusses the different factors (e.g. dosages, detention time, $\mathrm{pH})$ that affect the oxidation of $\mathrm{Fe}^{+2}$ and $\mathrm{Mn}^{+2}$ by using PP followed by direct filtration. Experiments are done for $\mathrm{Fe}^{+2}$ and $\mathrm{Mn}^{+2}=$ 1.50 and $1.0 \mathrm{mg} / \mathrm{l}$, respectively which represent iron and manganese concentrations in the Delta region, Egypt. The second group investigates the results of the first one on other combined concentrations of $\mathrm{Fe}^{+2}$ and $\mathrm{Mn}^{+2}$ by using direct filtration alone. The third group discusses the efficiency of using sedimentation if high concentrations of $\mathrm{Fe}^{+2}$ and $\mathrm{Mn}^{+2}$ exist. This phase includes flocculation, sedimentation and Filtration. included. The RSF is made of PVC pipe of internal diameter $=100 \mathrm{~mm}$ and includes 35 $\mathrm{cm}$ gravel layer with diameter $6: 25 \mathrm{~mm}$ and $75 \mathrm{~cm}$ of coarse sand with diameter 1.18:1.60 $\mathrm{mm}$. The Rate of Filtration is obtained by controlling the outlet filter valve.

\subsection{Chemicals:}

The simulated groundwater containing iron and manganese is made by adding ferrous sulfate heptahydrate $\left(\mathrm{FeSO}_{4} .7 \mathrm{H}_{2} \mathrm{O}\right)$ and manganese sulfate mono-hydrate $\left(\mathrm{MnSO}_{4} \cdot \mathrm{H}_{2} \mathrm{O}\right)$ to tap water. Potassium permanganate $\left(\mathrm{KMnO}_{4}\right)$ with $99.90 \%$ purity and aluminum sulphate hexadecahydrate $\left.\mathrm{Al}_{2}\left(\mathrm{SO}_{4}\right)_{3} 16 \mathrm{H}_{2} \mathrm{O}\right)$ were used as sources of $\mathrm{PP}$ and alum. Sodium hydroxide $(\mathrm{NaOH})$ was used to adjust $\mathrm{pH}$.

\subsection{Devices and Analyses:}

Iron and manganese measure devices were used to measure iron and manganese concentrations (Hanna, USA). Portable $\mathrm{pH}$ device was used to measure water $\mathrm{pH}$. The devices were calibrated before the study.

\subsection{Pilot plant:}

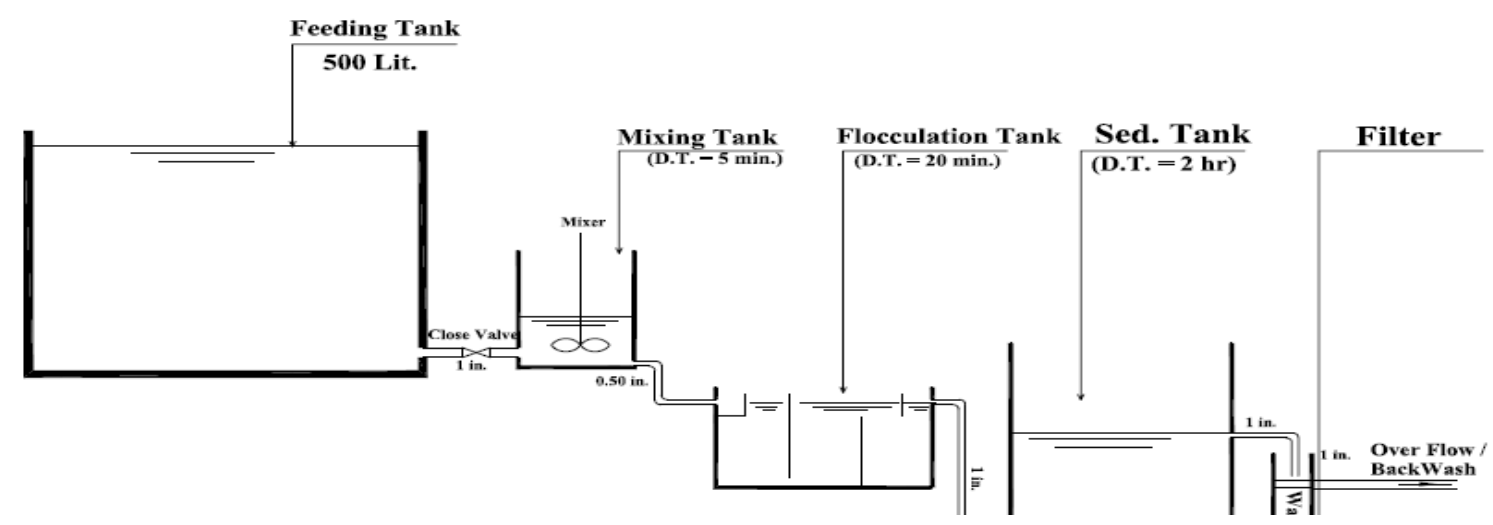

Fig. (1): Pilot Plant with mixing, flocculation, sedimentation and filtration tanks. When direct filtration mode is used, the flocculation and sedimentation tanks are removed.

Figure (1) shows the pilot plant, which is constructed for the study. It consists of feeding tank, process tank for adding and mixing chemicals, flocculation and sedimentation tanks and a Rapid Sand Filter (RSF). For $1^{\text {st }}$ and $2^{\text {nd }}$ phase experiments, the flocculation and sedimentation tanks are not

\section{RESULTS AND DISCUSSIONS:}

3.1. Group 1: study using Potassium Permanganate: 
In this group, the experiments were done for $\mathrm{Fe}^{+2}$ and $\mathrm{Mn}^{+2}$ concentrations $=1.50$ and 1.0 $\mathrm{mg} / \mathrm{l}$, respectively at constant $\mathrm{ROF}=150$ $\mathrm{m}^{3} / \mathrm{m}^{2} / \mathrm{d}$, discuss the removal efficiency of iron and manganese using potassium permanganate under different conditions like different dosages of PP, contact time, effect of $\mathrm{pH}$ and ROF effect. The experiments lasted for 6 hours before taking samples.

Effect of PP dosages: Fig. (2) shows the results of using different $\mathrm{PP}$ dosages for $\mathrm{Fe}^{+2}$ and $\mathrm{Mn}^{+2}$ removal. Using a dosage of $1 \mathrm{ppm}$ of PP can remove up to $97 \%$ of iron just after 10 minutes. For manganese, using PP enhances the removal process greatly at $\mathrm{pH}=7.0$. Using PP dose $=2.0 \mathrm{ppm}$-which is near to half of the theoretically calculated dose- can remove $66 \%$ of manganese after 10 minutes. Using doses near to the theoretical dose remove up to $80 \%$ of manganese in just 10 minutes. Increasing PP dosage more than the theoretical one has a bad effect on water. When the dosage of $4 \mathrm{ppm}$ is used, the water is colored pink from the effect of increased PP dosage. The increased PP quantity contains manganese according to the following equation [13]:

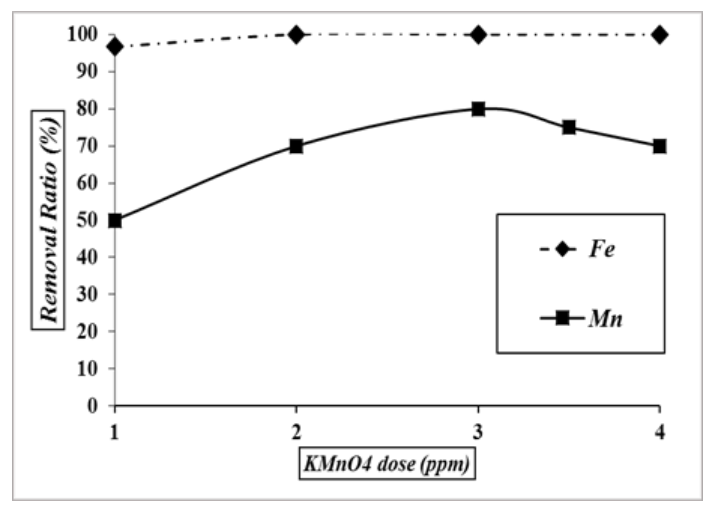

Fig. (2): Effect of using different PP doses on $\mathrm{Fe}^{+2}$ and $\mathrm{Mn}^{+2}$ removal (Initial $\mathrm{Fe}^{+2}$ and $\mathrm{Mn}^{+2}$ are 1.50 and $1.0 \mathrm{mg} / \mathrm{ll} \mathrm{pH}=7.0, \mathrm{ROF}=150 \mathrm{~m} / \mathrm{d}$ and $R T=10 \min$.)

$$
\begin{gathered}
\mathrm{KMnO}_{4}+8 \mathrm{H}^{+}+5 \mathrm{e}^{-} \\
\mathrm{Mn}^{+2}+\mathrm{K}^{+}+4 \mathrm{H}_{2} \mathrm{O} \ldots
\end{gathered}
$$

Therefore, a special care should be taken into consideration for choosing the PP dosage. These results agree with other studies that recommend using PP dosages near the theoretical ones [13].

Effect of Retention Time: The results for using PP dose $=2.0 \mathrm{ppm}$ for $\mathrm{RT}=5$ to 20 minutes are shown in Fig. (3). The oxidation process of iron using PP happens very fast. Complete iron oxidation needs less than 5 minutes. The oxidation process of manganese using PP also happens fast and is enhanced by increasing RT. At RT less than 5 minutes, about $66 \%$ of manganese is oxidized, however, at RT equals to 20 minutes increases the RR to $90 \%$.

Effect of pH: Fig. (4) shows results of $\mathrm{pH}$ effect on $\mathrm{Fe}^{+2}$ and $\mathrm{Mn}^{+2}$ oxidation by PP dose $=2.0 \mathrm{ppm}$ and $\mathrm{RT}=10 \mathrm{~min}$. It is shown that iron is oxidized at $\mathrm{pH}$ greater than 7.0 and much of manganese oxidation by using PP happens also at $\mathrm{pH}$ near to 7.0. Increasing $\mathrm{pH}$ to 8 and 9 , increases the RR to $75 \%$ and $85 \%$, respectively. Therefore, it is concluded that $\mathrm{pH}$ affects the process of $\mathrm{Fe}^{+2}$ and $\mathrm{Mn}^{+2}$ oxidation by PP slightly or in other words, they need $\mathrm{pH}$ greater than 7.0.

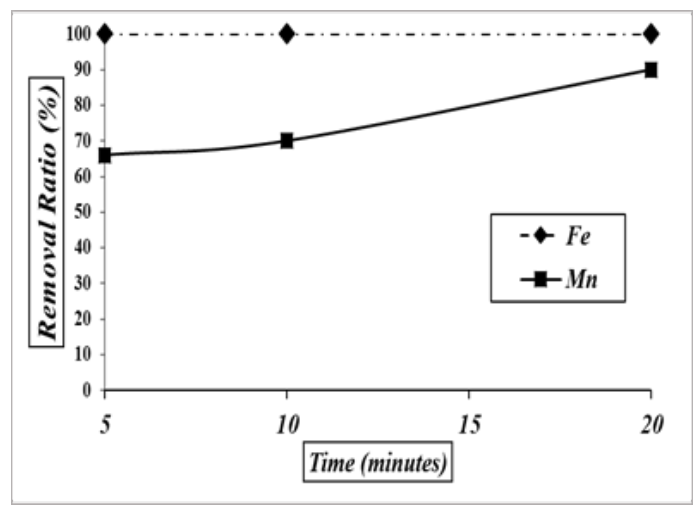

Fig. (3): Effect of retention time on $\mathrm{Fe}^{+2}$ and $\mathrm{Mn}^{+2}$ removal by $\mathrm{PP}$ (Initial $\mathrm{Fe}^{+2}$ and $\mathrm{Mn}^{+2}$ are 1.50 and $1.0 \mathrm{mg} / \mathrm{l}, \mathrm{pH}=7.0, P P=2.0 \mathrm{ppm}$ and $\mathrm{ROF}=150 \mathrm{~m} / \mathrm{d}$ ) 


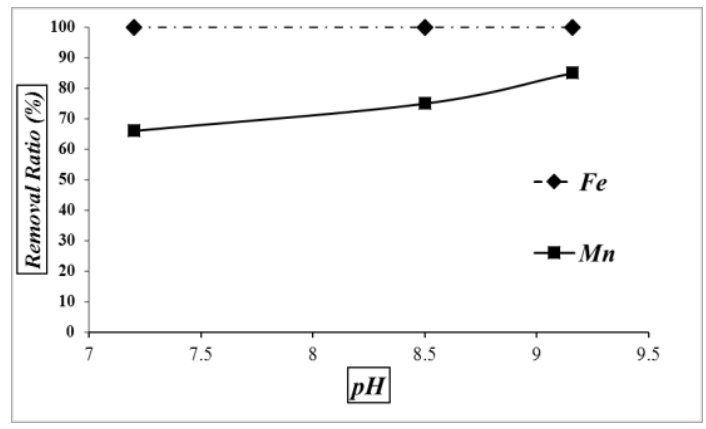

Fig. (4): Effect of $\mathrm{pH}$ on $\mathrm{Fe}^{+2}$ and $\mathrm{Mn}^{+2}$ removal by $\mathrm{PP}$ (Initial $\mathrm{Fe}^{+2}$ and $\mathrm{Mn}^{+2}$ are 1.50 and 1.0 $m g / l, P P=2.0 \mathrm{ppm} R O F=150 \mathrm{~m} / \mathrm{d}$ and $R T=10$ min.)

The obtained results agree with other studies which found that the required dose of PP to oxidize $\mathrm{Mn}^{+2}$ was less than that indicated by stoichiometry. It is thought that when $\mathrm{Mn}^{+2}$ is separated on the filter, it starts to coat the filter sands and convert it to work like green sand filter so the required dose becomes smaller [10]. The oxidation time ranges from 5 to 10 minutes, provided that the $\mathrm{pH}$ is over 7.0 [12]. On the other hand, some studies found that the required dosage is slightly more than the required theoretical dose at $\mathrm{pH}$ less than 8.0 [13] and so, the required dose should be determined accurately.

Rate Of Filtration (ROF) effect: Fig. (5) shows the results of experiments that discuss the effect of increasing ROF on $\mathrm{Fe}^{+2}$ and $\mathrm{Mn}^{+2}$ removal. $\mathrm{PP}$ dose $=2.0 \mathrm{ppm}$ was used for RT $=20$ min. For iron: increasing ROF from 150 to $180 \mathrm{~m} / \mathrm{d}$ does not affect the removal efficiency. At $\mathrm{ROF}=220 \mathrm{~m} / \mathrm{d}$, RR becomes

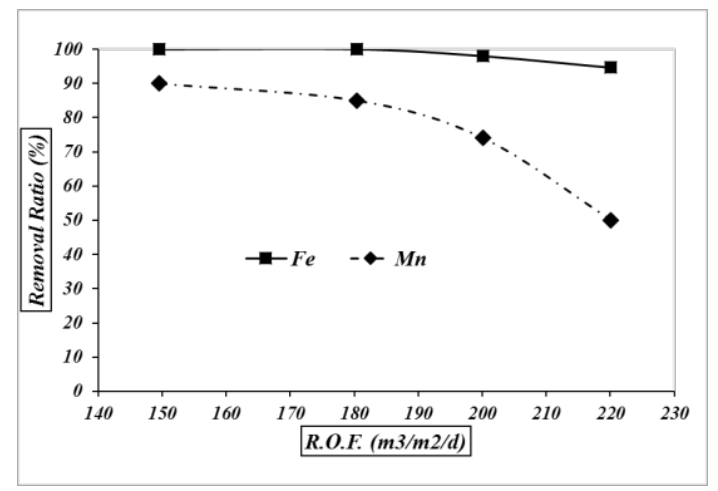

Fig. (5): Effect of R.O.F. on $\mathrm{Fe}^{+2} / \mathrm{Mn}^{+2}$ removal (Initial $\mathrm{Fe}^{+2} / \mathrm{Mn}^{+2}$ conc. is $1.50 / 1.0 \mathrm{mg} / \mathrm{l}, \mathrm{pH}=7.0$, $P . P .=2.0$ ppm and D.T. $=20 \mathrm{~min}$ )
Table (1): $\mathrm{Fe}^{+2} / \mathrm{Mn}^{+2}$ concentrations of phase 2 experiments

\begin{tabular}{|c|c|c|c|}
\hline $\begin{array}{c}\mathrm{Fe}^{+2} \\
(\mathrm{mg} / \mathrm{l})\end{array}$ & $\begin{array}{l}\mathrm{Mn}^{+2} \\
(\mathrm{mg} / \mathrm{l})\end{array}$ & $\begin{array}{c}\text { Combined } \\
\text { Conc. }(\mathrm{mg} / \mathrm{l})\end{array}$ & $\begin{array}{c}\text { PP } \\
\text { dose } \\
\text { (ppm) }\end{array}$ \\
\hline 1.5 & 1 & 2.5 & 2 \\
\hline 3 & 2 & 5 & 3.5 \\
\hline 5 & 3 & 8 & 5.5 \\
\hline 6 & 4 & 10 & 7 \\
\hline
\end{tabular}

$95 \%$. But in general, it is seen that iron removal is slightly affected by increasing ROF. For manganese: the biggest $R R$ is obtained at ROF equals $150 \mathrm{~m} / \mathrm{d}$. At ROF equals $220 \mathrm{~m} / \mathrm{d}$, the removal ratio becomes $50 \%$ only, therefore, it is obvious that manganese removal depends on ROF in contrast to iron. Therefore, ROF of 150-180 $\mathrm{m} / \mathrm{d}-(6.25-7.5 \mathrm{~m} / \mathrm{h})$ is recommended for $\mathrm{Mn}^{+2}$ and $150-220 \mathrm{~m} / \mathrm{d}(6.25-9.17)$ for iron. However, it is reported that the recommended ROF for $\mathrm{Mn}^{+2}$ removal is about $15-18 \mathrm{~m} / \mathrm{hr}$ where for iron is 6-7.5 which is considered totally different from our study [12].

\subsection{Group 2: Study results of Phase 1 on other $\mathrm{Fe}^{+2}$ and $\mathrm{Mn}^{+2}$ concentrations:}

In this group, experiments were done for different concentrations of iron and manganese with using half of the required stoichiometric dose of PP. Table (1) shows these concentrations and the used PP dose. The experiments started with ROF equals to 180 $\mathrm{m}^{3} / \mathrm{m}^{2} / \mathrm{d}, \mathrm{pH}=7.0$ and $\mathrm{RT}$ equals to 20 minutes. The experiments lasted for 24 hours.

Effect of using PP: Fig. (6) shows results of using half of the stoichiometric PP dose on the removal of $\mathrm{Fe}^{+2}$ and $\mathrm{Mn}^{+2}$ different concentrations. The figure shows that using PP is very efficient to oxidize and remove $\mathrm{Fe}^{+2}$ and $\mathrm{Mn}^{+2}$ at different concentrations, where using half of stoichiometric dose of PP can remove about $98 \%$ of $\mathrm{Fe}^{+2}$ and more than $90 \%$ of $\mathrm{Mn}^{+2}$ despite increasing combined concentrations to $10 \mathrm{mg} / \mathrm{l}$. 


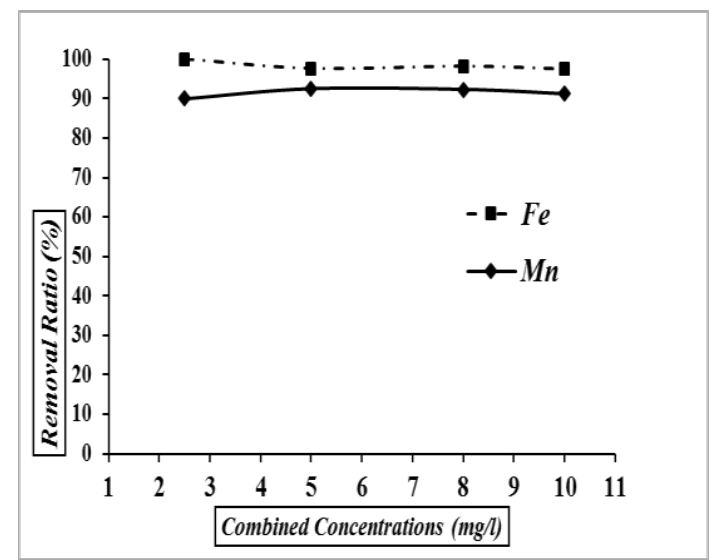

Fig. (6): Effect of using half dose of PP on removal of different concentrations of $\mathrm{Fe}^{+2}$ and $\mathrm{Mn}^{+2}$ (Initial $\mathrm{pH}=7.0, \mathrm{RT}=\mathbf{2 0} \mathrm{min}$. Samples are taken and analyzed after 8 hours from filter run start).

Filter clogging rate: Fig. (7) shows the change in ROF with time (in hours) for experiments of group 2. The change in ROF expresses the velocity of filter clogging at different concentrations. The figure shows that the ROF decreases with time as expected. This occurs as removed iron and manganese accumulate on filter media and start to clog the filter. It is shown that increasing $\mathrm{Fe}^{+2}$ and $\mathrm{Mn}^{+2}$ concentrations lead to rapid filter clogging. When concentrations of iron and manganese exceed $5.0 \mathrm{mg} / \mathrm{l}$, the removed particles cause rapid clogging of filters and decrease the period of filter run to be less than 12 hours. This period is not practical nor economical to be applied to water treatment plants as the ratio of backwash water will increase. And so, it is recommended that when these concentrations exceed $5.0 \mathrm{mg} / \mathrm{l}$ to use sedimentation before filtration. Other studies suggest using sedimentation when combined concentrations of $\mathrm{Fe}^{+2}$ and $\mathrm{Mn}^{+2}$ exceed $8.0 \mathrm{mg} / \mathrm{l} \quad[\mathbf{8}]$ or when iron concentration is greater than $5.0 \mathrm{mg} / 1$ [12].

\subsection{Group 3: Study using conventional treatment to remove High concentrations of $\mathrm{Fe}^{+2}$ and $\mathrm{Mn}^{+2}$ :}

This group of experiments deals with using conventional treatment to remove $\mathrm{Fe}^{+2}$ and $\mathrm{Mn}^{+2}$

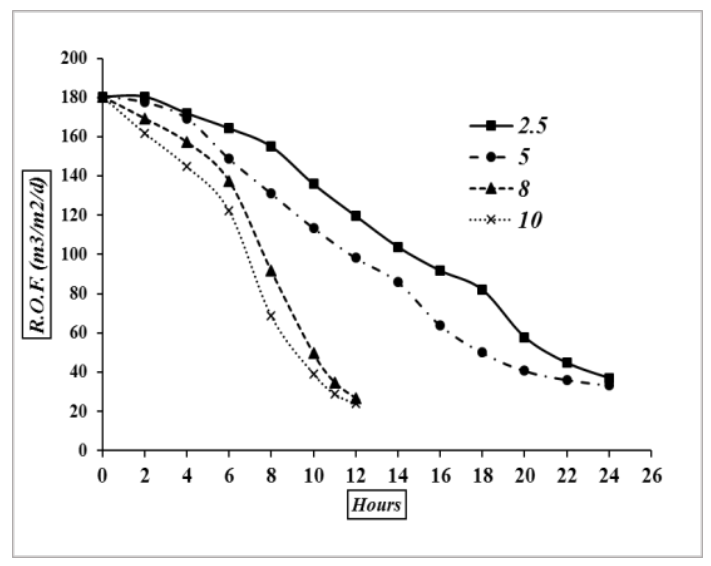

Fig. (7): Change in ROF of different concentrations of $\mathrm{Fe}^{+2}$ and $\mathrm{Mn}^{+2}$ (Initial $\mathrm{pH}=7.0$, $R T=20$ min. All experiments Started at $R O F=180$ $m / d)$

when found in high concentrations. The treatment consists of adding alum (with/without other chemicals), mixing with water for 5 minutes, flocculation for $25 \mathrm{~min}$., sedimentation for $2.0 \mathrm{hrs}$ and then filtration. This set discusses using alum alone, alum with PP and alum with increasing $\mathrm{pH}$.

Fig. (8) shows the results of these experiments. It is shown that using alum alone can remove high ratio of $\mathrm{Fe}^{+2}$. By using alum dose $=60 \mathrm{ppm}$, about $97 \%$ of $\mathrm{Fe}^{+2}$ can be removed. But, RR of $\mathrm{Mn}^{+2}$ does not exceed $18 \%$. Using PP with alum enhances $\mathrm{Mn}^{+2} \mathrm{RR}$ to reach about $63 \%$ but decreases $\mathrm{Fe}^{+2} \mathrm{RR}$ to $79 \%$ when PP dose $=5.0$ ppm used with alum dose $=40$ ppm. using alum alone with increasing water $\mathrm{pH}$ to over 10 leads to complete removal of iron and about $95 \%$ of $\mathrm{Mn}^{+2}$.

Another study found that $\mathrm{Fe}^{+2} / \mathrm{Mn}^{+2}$ removal by coagulation and clarification were about $18: 75 \%$ and $8: 24 \%$ for $\mathrm{Fe}^{+2} / \mathrm{Mn}^{+2}$, respectively for different concentrations of both. However, when PP was used, $\mathrm{Fe}^{+2} \mathrm{RR}$ was about $99 \%$ which is greater than our study results and $\mathrm{Mn}^{+2} \mathrm{RR}$ was $72 \%$ which are like the above results [14].

\section{CONCLUSIONS:}




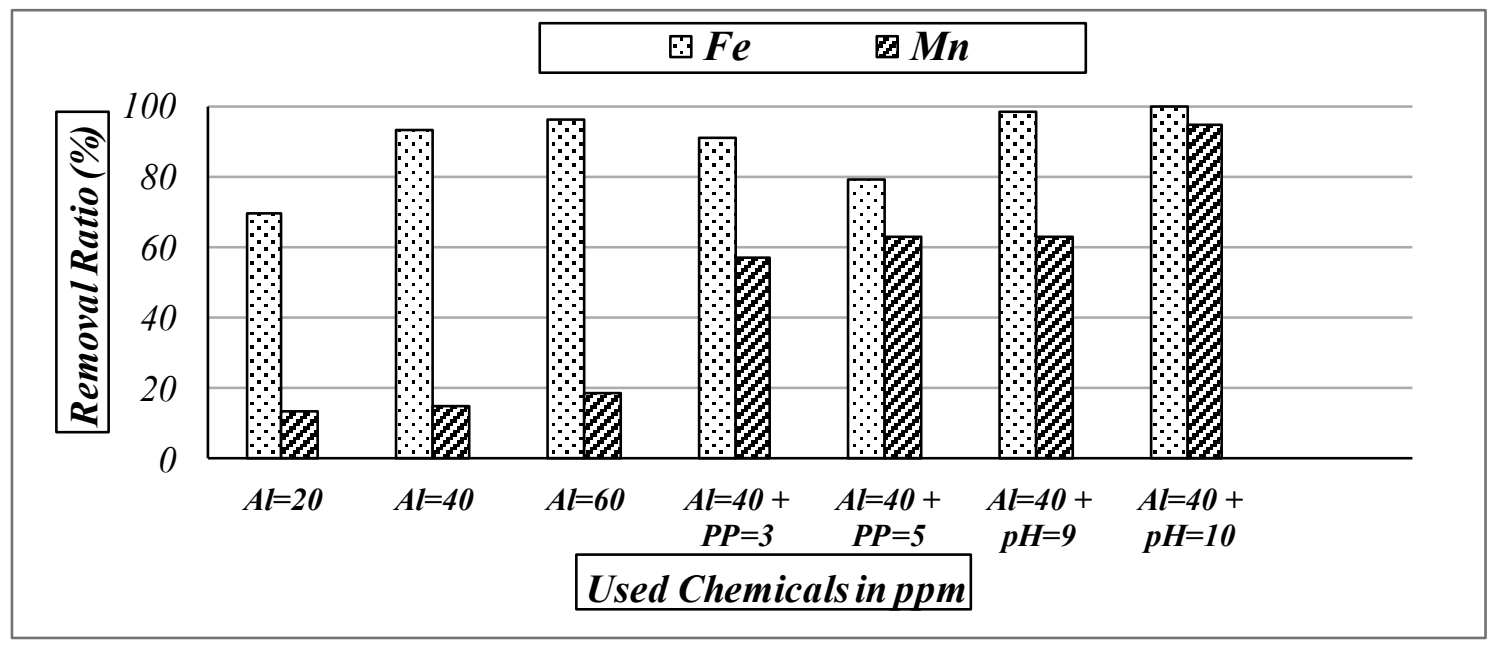

Fig. (8): Results of using conventional treatment for removal of $\mathrm{Fe}^{+2}=5.0 \mathrm{mg} / 1$ and $\mathrm{Mn}^{+2}=3.0 \mathrm{mg} / 1$ (Initial pH=7.0, All experiments Started at $\mathrm{ROF}=150 \mathrm{~m} / \mathrm{d}$ and samples are taken after 10 hours from filtration start).

Iron and manganese can be removed from groundwater by using oxidation by potassium permanganate followed by filtration which gives good results. By using doses near to half of the theoretically calculated dose, it can remove up to $100 \%$ and $90 \%$ of iron and manganese at $\mathrm{pH}=7.0$ over tested concentrations. Sedimentation is required when combined concentrations of iron and manganese are greater than $5.0 \mathrm{ppm}$ to increase the filtration period. Using conventional treatment of adding alum, flocculation, sedimentation and filtration can remove up to $97 \%$ and only $18 \%$ of iron and manganese, respectively. Using PP in addition to alum enhances manganese removal but decreases iron removal. However, using alum with increasing $\mathrm{pH}$ to 10 leads to $100 \%$ and $95 \%$ of $\mathrm{Fe}^{+2}$ and $\mathrm{Mn}^{+2}$ removal and increases filter working period.

\section{RECOMMENDATIONS:}

Using PP: PP is considered a very good selection for the process of iron and manganese removal. The experiments show that using dosages near to half of the required theoretical dose at normal $\mathrm{pH}$ and retention time of 20 minutes can remove iron completely and $90 \%$ of manganese. However, the dose should be determined very accurately to prevent water coloring.

Using sedimentation: sedimentation is required when iron and manganese combined concentrations exceed $5.0 \mathrm{mg} / 1$ to allow longer filtration periods.

Using Alum: using alum with sedimentation alone cannot remove high ratio of manganese. However, using PP with alum affect $\mathrm{Fe}^{+2}$ removal. Using alum while raising $\mathrm{pH}$ to 10 leads to remove high ratio of both $\mathrm{Fe}^{+2} / \mathrm{Mn}^{+2}$ concentrations.

\section{REFERENCES}

1. Ahmed R., E. Saafb, Mohamed A. Dawoud: 'Desalination of brackish groundwater in Egypt', Desalination, 152, pp. (19-26), 2002.

2. Qingfeng C., Lichao N, Linlin B., et al.: 'Interactions between ammonia, iron and manganese removal using pilot-scale biofilters' Journal of Water Supply: Research and Technology, AQUA, in press, 2017.

3. Demir, Neslihan Manav. "Experimental Study of Factors that Affect iron and manganese Removal in Slow Sand Filters and Identification of Responsible Microbial Species." Polish Journal of Environmental Studies 25.4: 1453-1465, 2016.

4. Azrin M., Mohd N., Mohd R., et al: 'Removal of iron and manganese Using Cascade Aerator and Limestone Roughing Filter' Materials Science Forum, 1662-9752, Vol. 857, pp 509-513, 2016.

5. R. El Araby, S. Hawash, G. El Diwani.: 'Treatment of iron and manganese in simulated groundwater via ozone technology', Desalination, 249, pp. (13451349), 2009.

6. Wen-Hsiang C., Yung-Hsu H., Chih-Chao W., et al: 'The on-site feasibility study of iron and manganese removal from groundwater by hollow-fiber microfiltration', Journal of Water Supply: Research and Technology -AQUA, pp. (391-401), 2011.

7. Jutta K. Piispanen \& Jarmo T. Sallanko: 'Mn(II) removal from groundwater with manganese oxide coated filter media', Journal of Environmental 
Science and Health, Part A: Toxic/Hazardous Substances and Environmental Engineering, 45:13, 1732-1740,2010.

8. John C., Mark T.: 'iron and manganese removal handbook', 2nd edition, American Water Works Association, 2015.

9. P. Roccaro, C. Barone, G. Mancini, et al: 'Removal of manganese from water supplies intended for human consumption: a case study', Desalination, 210, pp. (205-214), 2007.

10. Piaw P., Jatuporn W., Wen-Hsiang C., et al: 'Removal of manganese(II) and iron(II) from synthetic groundwater using potassium permanganate', Desalination and Water Treatment, 52, p. 5942-5951, 2014.

11. Lee H. Odell: 'Treatment technologies for Groundwater', 1st edition, American Water Works Association, 2010.
12. K. M. Johnson, D. D. Ratnayaka, M. J. Brandt: 'Twort's Water Supply', 7th edition, Elsevier Ltd CO., 2016.

13. G. Khadse, P. Patni1, P. Labhasetwar: 'Removal of iron and manganese from drinking water supply', Sustain. Water Resour. Manag. 1:157-165, 2015.

14. Zogo D., Bawa L., Soclo H. and Atchekpe D.: 'Influence of pre-oxidation with potassium permanganate on the efficiency of iron and manganese removal from surface water by coagulation-flocculation using aluminium sulphate: Case of the Okpara dam in the Republic of Benin', Journal of Environmental Chemistry and Ecotoxicology Vol. 3(1), pp. 1-8, January 2011. 